Article

\title{
How to Change the World: An Introduction to Alain Badiou's Subtractive Ontology, Militant Subjectivity, and Ethic of Truths ${ }^{1}$
}

Kelly Louise Rexzy P. Agra

\begin{abstract}
In one of Alain Badiou's interviews, he diagnoses that today's world is suffering from a double-edged crisis. At the objective level, we have the crises brought about by capitalism. But at the same time, he notes that at the subjective level, we are confronted with an obscure vision of the future, which makes the solution to the objective crisis more problematic.

This work provides a concise introduction to what I refer to as the four-part solution of Badiou to the existing crises the contemporary world is faced with. This consists of, first, founding of an affirmative logic to combat the crisis of negativity in contemporary philosophy. Second, laying down an ontology capable of thinking about the possibility of radical immanent change as a response to the declaration regarding the end of metaphysics. Third, constructing a new understanding of ethics that can go beyond the limitations of an ethics based on universal human rights and ethics of difference or compassion. And fourth, a new theory of the subject that shall serve as a manifesto for a new form of subjectivity as is required in the contemporary world.
\end{abstract}

Keywords: Badiou, subtractive ontology, militant subjectivity, ethic of truths

\footnotetext{
${ }^{1}$ Earlier versions of the Introduction and Parts 1 and 2 have been published under the CSSTRP conference proceedings; Kelly Agra, "Thinking in the End Times: From Logic to Anthropology," in Social Science Teaching, Research and Practice: Consolidating Lessons and Charting Directions (Conference Papers, Vol. 1), ed. by Lorelei C. Mendoza (Baguio City: College of Social Sciences, University of the Philippines Baguio, 2016), 89-106. Also, some discussions have been lifted from Kelly Agra, “The World as 'Is' and the World as 'Ought': Contemporary Philosophy and the Crisis of Subjectivity," in Philosophy in the Contemporary World 22:2 (2015), 68-79.
}

(C) 2017 Kelly Louise Rexzy P. Agra

https://www.kritike.org/journal/issue 21/agra december2017.pdf

ISSN 1908-7330 
I am a philosopher. And I think that the business of a philosopher is to be optimistic ... Because if you are pessimistic, finally, there is no use of yourself. Because to be pessimistic, there is no necessity to be a philosopher, the situation suffices. And so, to say to people something which can be useful for them, we must have some hope to transform the world, and go to the direction of a better world, if it is possible. - Alain Badiou

\section{Introduction: The World as 'Is' is in Crisis}

$\mathrm{O}$ ne of the famous scholars of the late twentieth century, Francis Fukuyama, wrote in his article "The End of History?" that "liberal democracy may constitute the 'end point of mankind's ideological evolution' and 'the final form of human government,' and as such constituted the 'end of history." 3

The philosopher Slavoj Žižek in his book Living in the End Times, diagnoses contemporary society and confronts the question, what kind of 'end time' are we living in? Insofar as Fukuyama is concerned, this consists of liberal democracy having reached the peak of its ideal, and that the best course of action is the complete implementation of the principles of liberty and equality. ${ }^{4}$ Mark Fisher, in addressing the question, "Is there no alternative?" echoes the sardonic remark of Fredric Jameson and Slavoj Žižek: as if "it is easier to imagine the end of the world than it is to imagine the end of capitalism." ${ }^{5}$ Sardonic, I say, because Žižek in Living in the End Times asserts the opposite: liberal democracy with its twin economic model, capitalism, is "approaching an apocalyptic zero-point."6 For him, the inconsistencies of liberal democratic capitalism are exploding in our globalized world, and this is not because of 'incomplete implementation' or as a standard capitalist views them, 'temporary, correctable glitches' in the functioning of the system. For Žižek, such inconsistencies must be viewed instead as moments of truth, as 'symptoms' in the psychoanalytic sense, as "exceptions" that "allow us to

\footnotetext{
2 Alain Badiou, “On Optimism," The Nexus Institute (2012), 07:30, $<\underline{\text { http://y2u.be/o6O d1DVk3U }>\text {. }}$

${ }^{3}$ Francis Fukuyama, The End of History and the Last Man (New York: The Free Press, 1992), xi. The article was published in The National Interest in the summer of 1989 . See also, Francis Fukuyama, "The End of History?" in The National Interest 16 (1989), 3-18.

${ }^{4}$ The general tenor of his thought was that despite the problems liberal democracy is facing, these problems are only the result of "the incomplete implementations of the twin principles of liberty and equality ... rather than flaws in the principles themselves." Fukuyama furthers that, while stable liberal democracy cannot yet be achieved in other states, "the ideal of liberal democracy could not be improved on." Fukuyama, The End of History and the Last Man, xi.

${ }^{5}$ Mark Fisher, Capitalist Realism: Is There No Alternative (UK: O Books, 2009), 2.

${ }^{6}$ Slavoj Žižek, Living in the End Times (London: Verso, 2010), $\mathrm{x}$.
} 
grasp the functioning of the system"7 in its internal inconsistency. Žižek diagnoses that our world today is being haunted by what he calls the "four riders of the apocalypse" comprised by "ecological crisis, the consequences of the biogenetic revolution, imbalances within the system (problems with intellectual property; forthcoming struggles over raw materials, food, and water), and the explosive growth of social divisions and exclusions." ${ }^{8}$ Simply put, our world today is undergoing a crisis.

The significance of Žižek's analysis lies in providing us a different angle through which we can understand the world situation. He powerfully argues that the problems we encounter today-crimes, poverty, discrimination, global warming, etc.-should not be looked at as psychological/subjective problems, but as results of the violence deployed by the system we are in. From Žižek's perspective, it is not enough to punish wrongdoers, to make people aware of the catastrophic consequences of people's consumption and way of life to the environment, or to continually give charity to the poor. What we need is an unrelenting courage to question why crimes, ecological crisis, poverty, and social divisions are being sustained in the first place, in a supposed to be free, democratic, and globalized world, and shatter the 'insensitivity to the systemic violence that had to go on in order for our comfortable lives to be possible. ${ }^{9}$

Badiou agrees with Žižek on the point that at the objective level, the crisis we are experiencing is caused by capitalism. But he points out that there is yet another aspect of the problem which makes the solution to the objective crisis seem to be even more impossible: a subjective crisis. For Badiou, this means that the difficulty of questioning the global order lies in the difficulty of questioning our very own way of life. Badiou has identified this as a fundamental problem which the younger generation in particular, but also humanity in general, is confronted with. In his terms, this predicament consists in an "obscure vision of the future."10 In an interview, Badiou remarks that this problem has two aspects. One poses the question 'can we continue as now?' The other asks the question 'if continuity is not the solution, if one recognizes the impossibility of sustaining this kind of life against the backdrop of the ongoing problems of social inequality, social divisions and poverty, if one ever desires to change the way things are, how will such change be possible?' In Badiou's words: “How is it possible to

\footnotetext{
${ }^{7}$ Slavoj Žižek, "Badiou: Notes From an Ongoing Debate," in International Journal of Žižek Studies, 1:2 (2007), 4.

8 Žižek, Living in the End Times, $\mathrm{x}$.

${ }^{9}$ Slavoj Žižek, Violence: Six Sideways Reflection (New York: Picador, 2008), 9.

${ }^{10}$ Badiou, "On Optimism."

(c) 2017 Kelly Louise Rexzy P. Agra

https://www.kritike.org/journal/issue 21/agra december2017.pdf

ISSN 1908-7330
}

(c) BY-NC-ND 
invent a new form of life?"11 What does the phrase "another way of doing things' point at?

This entire line of questioning leads to a core issue in Badiou's philosophy: the thinkability of the actualization and materiality of change. Adrian Johnston, in the Preface to his book Badiou, Žižek, and Political Transformations: The Cadence of Change, makes the optimistic remark that "the Badiouian-Žižekian engagement with politics gives a strong reason for hoping that thinking can in fact generate change." 12 This is echoed by Ed Pluth who describes Badiou's philosophy as one that promotes an "intelligence of change." 13 Meanwhile, in contrast to an optimistic tone, Bruno Bosteels uses "Can Change Be Thought?" as an interrogative title to his interview article with Badiou, appended at the end of his book, Badiou and Politics. These three works attest to the growing intellectual orientation in Western political-social philosophy that explores the possibility of a renewed materialist theory of radical change, tied to a reconstructed theory of subjectivity that became most pronounced in the philosophy of Badiou. Since the said idea's articulation in Badiou's Theory of the Subject, down to its elaboration in Being and Event and Logics of Worlds, floodgates of debate have been opened up, and this idea lured a lot of leftist thinkers like Žižek, Bosteels, and Johnston.

Badiou stresses that the purpose of philosophy is to provide a way of understanding and confronting the problems of the world and of life. However, for him, contemporary philosophy cannot do this after the ethicolinguistic turn ${ }^{14}$ because philosophy already rendered itself compatible with the current ideology that declares "there are only bodies and languages." 15 In confrontation with this, he asserts that there is a need to bring back the concept of truth, because it is the concept of truth which is concerned with going beyond limits, going beyond the ordinary towards the authentic lifethe life which, for him, is barred in today's world.

Badiou's revival of the concept of truth is what led his thinking to the very idea of the 'event' - one of the central concepts of his philosophy. For

\footnotetext{
${ }^{11} \mathrm{Ibid}$.

${ }^{12}$ Adrian Johnston, Badiou, Žižek and Political Transformations: The Cadence of Change, (USA: Northwestern University Press, 2009), xxiv.

${ }^{13}$ See Ed Pluth, Badiou: A Philosophy of the New (New York: Polity Press, 2010), back cover.

14 In the discussion pertaining to the incommensurability of differences most pronounced in the linguistic turn in philosophy, this incommensurability was not only at the level of language and epistemology, but most importantly, at the level of culture and ethics. This instigated a shift not only to a preoccupation with language but also to morality and/or ethics. Hence the term ethico-linguisitc turn.

${ }^{15}$ Alain Badiou, Logics of Worlds, trans. by Alberto Toscano (London: Bloomsbury, 2013), 1-2.
} 
Badiou, truth is not always possible. Truth, he argues, needs a supplement ${ }^{16}-$ an occurrence, that disrupts the regular functioning of our world. This disruptive occurrence is what he calls an event.

The term 'event' is Badiou's name for the beginning of change. An event is what sparks an idea that a change in the distribution of possibilities is possible. The event is what opens up the possibility of truth and the coming to being of worlds. ${ }^{17}$

The entire discourse surrounding the concepts 'being,' 'event,' 'worlds,' 'subject,' and 'truth' is the content of Badiou's subtractive ontology (Being and Event), logic of appearing (Logics of Worlds), and ethic of truths (Ethics: An Essay on the Understanding of Evil). These are Badiou's responses to what he sees as the inability of contemporary Western ideology, including contemporary Western philosophy, to provide enough solution to our double-edged crisis. His proposal consists of four parts: the founding of an affirmative logic, the laying down of an ontology capable of thinking about the possibility of radical immanent change, the construction of a new understanding of ethics, and a new theory of the subject on the basis of the first two.

This paper focuses on these four. It begins with Badiou's diagnosis of the contemporary form of ethics and social critique which constitute our existing ideology. This is followed by what he sees as the limitation of contemporary ideology in relation to the authentic life. Then, in the attempt to address the contemporary predicament using Badiou's philosophy, this paper argues that his proposal consists of four-parts: logic, ontology, a theory of the subject, and an understanding of ethics.

\section{Thinking in the End Times}

In the eyes of Badiou, the general determination of ethics today is the one which is represented by an ethics of the universal rights of the human individual. It prescribes a way of understanding our basic human orientation by defining our most elementary feature, that we are beings who "are born free and equal in dignity and rights ... endowed with reason and conscience and should act towards one another in a spirit of brotherhood." 18 This is asserted in 'The Universal Declaration of Human Rights.' Badiou remarks,

${ }^{16}$ Alain Badiou, Being and Event, trans. by Oliver Feltham (New York: Continuum, 2005), 355; Alain Badiou, Ethics: An Essay on the Understanding of Evil trans. by Peter Hallward (New York: Verso, 2000), 41; Alain Badiou, "Ethic of Truths," in Pli: Warwick Journal of Philosophy 12 (2001), 250.

${ }^{17}$ Badiou, Being and Event, xii.

18 United Nations General Assembly, Resolution 217 A, “The Universal Declaration of Human Rights," 10 December 1948, <http://www.un.org/en/universal-declaration-humanrights/index.html $>$, Art. 1.

(c) 2017 Kelly Louise Rexzy P. Agra

https://www.kritike.org/journal/issue 21/agra december2017.pdf

ISSN 1908-7330

(c) BY-NC-ND 
According to the way it is generally used today, the term 'ethics' relates above all to the domain of human rights, 'the rights of man' - or, by deviation, the rights of living beings ... We are supposed to assume the existence of a universally recognizable human subject possessing 'rights' that are in some sense natural: the right to live, to avoid abusive treatment, to enjoy 'fundamental' liberties. These rights are held to be self-evident, and the result of a wide consensus. 'Ethics' is a matter of busying ourselves with these rights, of making sure that they are respected. ${ }^{19}$

The core of such ethical orientation for him, rests on the assumption that we share a general consensus of what could be considered as those that violate our 'inalienable rights' and 'freedom.' This means that as human beings, we share an implicit agreement on what is harmful or unjust, which can be the basis for a universal determination of what is good. Badiou reads this as embodying the imperative of identifying first the opposite of what is to be considered good, viz., the principle of evil. Ethics is to proceed and determine its course from the standpoint of what is considered evil. What is good is everything that is against and that prevents the occurrence of torture, slavery, inequality.

Badiou argues that this is essentially what theorists of the 'natural law' retained from the categorical imperative of Immanuel Kant. He says that "ethics is conceived here both as an a priori ability to discern Evil, [...] and the ultimate principle of judgement." 20 This means that we presume a natural law regarding what is barbarian and that we understand the Good as that which "intervenes visibly against Evil which is identifiable a priori." 21 The power of this doctrine, Badiou accounts, is its self-evidence ${ }^{22}$-the self-evidence of suffering being highly visible and that we have an immediate disposition to move towards its impediment. The fact that from experience, we recognize that we can identify suffering and injustices when we see them and thus construct the law according to its prevention is the very foundation of an ethics of 'universal human rights.'

Meanwhile, the refocusing of philosophy on the discourse of finitude went side by side with changes in ethics. Philosophies that centered on linguistic incommensurability had moral counterparts, such as the respect of

\footnotetext{
${ }^{19}$ Badiou, Ethics, 4.

${ }^{20}$ Ibid., 8.

${ }^{21}$ Ibid., 8 .

22 Ibid., 9.
} 
differences, multiculturalism, and the politics of tolerance. This work refers to this form of ethics as the ethics of difference.

It is not a hidden fact that the philosopher most notable for this is Emmanuel Levinas. He critiqued the Heideggerian formulation of "ontology is first philosophy," deposed it, and put ethics at center stage. The ethical radicalism Levinas upheld in Totality and Infinity goes against a Greek-origin of ethics which presumes that action must be in conformity with the rationality of being. For Levinas, it is impossible to restrict within the limits of the logic of the Same or identity the being of the Other. This is because the Other's being rests on absolute infinity. If there is to be any conception of ethics therefore, it must be "grounded in the immediacy of an opening to the Other which disarms the reflexive subject." 23

It is upon this theoretical edifice that the ethics of difference is founded. Contemporary ethics, like those of culturalism, Badiou argues, amounts to "'the recognition of the other', to the 'ethics of differences', to 'multiculturalism', or to the good old-fashioned 'tolerance', which consists of not being offended by the fact that others think and act differently from you." 24 It runs a firm stance against racism, against hegemony, or against a substantialist nationalism that denies or excludes others. In the words of Badiou, "Its great ideal is the peaceful coexistence of cultural, religious, and national 'communities', the refusal of 'exclusion'." 25 By virtue of the reality that we are all different, and this difference is in itself what prevents us from identifying a single determination of ourselves, of others, and of the world, it is only by taking this as point of departure that we can start living humanely.

Correspondingly, the ethics of difference and compassion (embedded in the ethics of universal human rights), Badiou notes, are also the founding blocks of the dominant theoretical forms of social critique today. One of these is espoused by the critical theorist, Theodor Adorno, namely, Negative Dialectics. The goal of thinking for him is precisely to prevent the repetition of the banality of Auschwitz. ${ }^{26}$ Under the logic of Negative Dialectics, the non-identity of thought and its negativity towards itself should be the ground of all thinking. ${ }^{27}$ Anything that prescribes or advances a unified concept of things must be dismissed.

${ }^{23}$ Ibid., 19.

${ }^{24}$ Ibid., 20.

${ }^{25}$ Ibid., 26.

26 Theodor Adorno, Metaphysics: Concepts and Problems trans. by Edmund Jephcott (Cambridge: Polity Press, 2001), 116. See also, Mark Horkheimer and Theodor Adorno, Dialectic of Enlightenment: Philosophical Fragments trans. by Edmund Jephcott (Stanford, California: Stanford University Press, 2002).

${ }^{27}$ Theodor Adorno, Negative Dialectics trans. by E.B. Ashton (New York: Continuum, 1999), 365.

(c) 2017 Kelly Louise Rexzy P. Agra

https://www.kritike.org/journal/issue 21/agra december2017.pdf

ISSN 1908-7330

$((c))$ BY-NC-ND 
Another one is the view of the liberal communist Antonio Negri who does away with Adorno's hyper-negativity and proposes instead a Spinozistic faith on the inherent evolutionary creativity of capitalism. Badiou notes that for Negri, capitalism is now working towards the direction of actualizing the ideals of communism. He writes that "Antonio Negri, but also Louis Althusser, thinks that the Hegelian dialectics was too negative, too subjective and too indifferent to the absolute potency of Nature, of Life, of the movement of History." ${ }^{28}$ And so, they ally themselves with Spinoza, because they find in him "a model of philosophy [...] which is without negation." 29

Badiou stresses that contemporary Western philosophy together with the ethics of difference and compassion fit the contemporary ideology that declares "there are only bodies and languages." 30 In the second volume of Being and Event entitled Logics of Worlds, Badiou explains that this statement is "the axiom of contemporary conviction." ${ }^{31} \mathrm{He}$ names it "democratic materialism.' He writes:

Democratic materialism. The individual as fashioned by the contemporary world recognizes the objective existence of bodies alone ... In order to validate the equation 'existence $=$ individual $=$ body', contemporary doxa must valiantly reduce humanity to an overstretched vision of animality. 'Human rights' are the same as the rights of the living. The humanist protection of all living bodies: this is the norm of contemporary materialism. Moreover, it is essentially a democratic materialism. That is because the contemporary consensus, in recognizing the plurality of languages, presupposes their juridical equality. Hence, the assimilation of humanity to animality culminates in the identification of the human animal with the diversity of its sub-species and the democratic rights that inhere in this diversity ... Communities and cultures, colours and pigments, religions and clergies, uses and customs, disparate sexualities, public intimacies and the publicity of the intimate: everything and everyone deserves to be recognized and protected by the law. ${ }^{32}$

28 Alain Badiou, "Affirmative Dialectics: from Logic to Anthropology," in The International Journal of Badiou Studies, 2:1 (2013), 2.

${ }^{29} \mathrm{Ibid} ., 2$.

${ }^{30}$ Badiou, Logics of Worlds, 1-2.

${ }^{31}$ Ibid., 1-2.

${ }^{32}$ Ibid., 1-2.

(c) 2017 Kelly Louise Rexzy P. Agra

https://www.kritike.org/journal/issue 21/agra december2017.pdf

ISSN 1908-7330

(cc) BY-NC-ND 
Democratic materialism he says, "is in the process of becoming the enveloping ideology for this new century." 33 As in the case of an ethic of human rights, the body, in so far as its vulnerability to victimhood is concerned, has become man's identifying factor and served as the basis for his rights. Badiou interprets this as contemporary ideology's form of materialism. By materialism, this means the brute insistence that everything that actually exists is material or physical. ${ }^{34}$ Thus, the insistence that the body is the ground of morality or ethics is a form of materialism insofar as it does not refer to any transcendent or symbolic entity or forms or principles, just the "immanence of incarnate beings." "35 Meanwhile, the emphasis on the incommensurable differences in our systems of language, cultures, communities, and perspectives is what for Badiou orients our sense of democracy. In the contemporary 'democratic'-or as Badiou interchangeably calls 'Western'-order, these differences must be welcomed and given free expression. In a simple note, democratic materialism is Badiou's term for the great motor that drives our thinking in what Žižek calls, the end times. ${ }^{36}$

\section{Confronting the Question of the World as 'Ought': The Need for a New Logic and a New Anthropology}

For Badiou, it is easy to see what the democratic materialist ideology amounts to: an anthropology that equates man simply with his capacity to suffer and be a victim, and his incapacity to pursue a good that transcends, and, in fact, ignores the brute reality of difference and appeals to our generic humanity. Badiou stresses that when confronted with the question of change, its only proposal is to survive and be tolerant.

\section{Man: a biological species, a 'biped without feathers'}

Badiou explains that the ethics of human rights begins with the identification of suffering that actually splits the human subject into two: a passive subject that suffers, and an active subject that judges that it must be

33 Ibid., 4.

${ }^{34}$ It has to be noted that this idea of materialism is different from what Badiou's brand of materialism. Regarding this topic, Ed Pluth comments that the materialism of capitalism is still an 'idealist materialism' owing to the fact that it introduces hierarchy of beings: the rich and the poor, the good guys and the bad guys, etc. See Ed Pluth's "The Black Sheep of Materialism: The Theory of the Subject," in Badiou and Philosophy ed. by Sean Bowden and Simon Duffy (Edinburgh: Edinburgh University Press, 2012), 99-112.

${ }^{35}$ Adrian Johnston, Prolegomena to Any Future Materialism - Volume One: The Outcome of Contemporary French Philosophy (Illinois: Northwestern University Press, 2013), 13.

${ }^{36}$ See Žižek's Living in the End Times.

(c) 2017 Kelly Louise Rexzy P. Agra

https://www.kritike.org/journal/issue 21/agra december2017.pdf

ISSN 1908-7330

(c) BY-NC-ND 
stopped by all available means. ${ }^{37}$ Put in the case of charity work or social welfare movements, for instance, the character of man is divided into the suffering-victim-man defined by his misfortunes, and the rich-healthybenefactor who is identified by his sensitivity and exercise of good conscience. What this alludes to is the fact that, in a situation that calls for an 'ethical response,' there is always the necessary coexistence of the suffering victim and the capable benefactor, without which, there can never be an 'ethical act.' Because we must act in accordance to "the spirit of brotherhood," 'ethics' is only for the 'privileged man of conscience' to exercise, towards an Other whose subjectivity is identified simply with his capacity to suffer.

For Badiou, this ominously downgrades the definition of man to a "living organism pure and simple." 38 It reduces 'humanity' to the "status of victim, of suffering beast, of emaciated, dying body," 39 and equates him with his "animal substructure." $40 \mathrm{He}$ adds, "To be sure, humanity is an animal species. It is mortal and predatory. But neither of these attributes can distinguish humanity within the world of the living." 41 It is not our victimhood which makes us what we are. But rather, our capacity to be more than this-our capacity to concentrate our force and direct our existence in pursuit of a conviction. "Beyond this," Badiou says, "there is only a biological species, a 'biped without feathers'." 42

\section{Tolerance: as an ideological category}

His next point of contention against democratic materialism involves the ethics of difference which for him bred, in our time, another ideology, the communitarian-particularist kind.

Another philosopher who echoes Badiou's attack on the issue of tolerance is Žižek, who explains that the "Respect for others' beliefs as the highest value can only mean two things: (1) either we treat the other in a patronizing way and avoid hurting him in order not to ruin his illusions, or (2) we adopt the relativist stance of multiple 'regimes of truth,' disqualifying as violent imposition any clear insistence on truth." 43

Both of these stances however are problematic. In the first case, instead of an authentic respect for the Other, what one expresses is a distant engagement in order not to see how thoroughly 'other' the Other is. Žižek

\footnotetext{
${ }^{37}$ Badiou, Ethics, 10.

${ }^{38}$ Ibid., 11.

${ }^{39}$ Ibid.

${ }^{40}$ Ibid.

${ }^{41}$ Ibid.

${ }^{42}$ Ibid., 12. Or as Žižek would remark: in renouncing "big ideological causes, what remains is only the efficient administration of life." Žižek, Violence: Six Sideways Reflection, 40.

43 Žižek, Violence: Six Sideways Reflection, 139.
} 
uses Sigmund Freud's analysis in discussing the problems of racism and discrimination that immigrants face. For Žižek, these actions are motivated by the experience of violence in sustained difference. He explains that the Other, the neighbor, is viewed as "a traumatic intruder ... whose different way of life disturbs us," s/he "throws the balance of our way of life off the rails." 44 Zizek notes that the offensive difference of the Other, "when it comes too close ... [may]give rise to an aggressive reaction at getting rid of this disturbing intruder." 45

Meanwhile, the second stance - the acceptance of the relativist stance of multiple regimes of truth that also plagues philosophy today-in Žižek's diagnosis, simply accepts that differences must just be 'tolerated' rather than 'overcome.' 46 Under this ideology, particularism, otherness - today exhibited in the discourses on the diversity of cultures and religions, of expressions of sexuality, of technological specialization, of functions and skills - are used as a right, a protective barrier against any form of intervention, even political struggle. With the recognition of the general character of today's world as free and democratic, situations that call for a militant firmness to intervene against barbarism are glossed over. In Žižek's words, it breeds “blindness to oppression on behalf of 'respect' for the Other's culture." ${ }^{47}$ What this suggests is an ethical gesture that backfires against itself in reality, in which the very limit of an ethics of difference becomes visible. For Žižek, true respect means treating the other as a serious adult, responsible for his or her belief. ${ }^{48}$ To tolerate is to entrench an identity (which is actually non-fixed), and to assume its totality.

It has to be noted that Žižek is not at all endorsing another universalist-totalitarian point of view in his critique of multiculturalism. As he remarks:

Actual universality, is not the deep feeling that above all differences, different civilizations share the same base values, etc.: actual universality appears (actualizes itself) as the experience of negativity, of the inadequacy-toitself of a particular identity. ${ }^{49}$

\footnotetext{
${ }^{44}$ Ibid., 59.

${ }^{45} \mathrm{Ibid}, 59$.

${ }^{46}$ Slavoj Žižek, "Tolerance as an ideological category," in Critical Inquiry 34:4 (2008),

${ }^{47}$ Žižek, Violence: Six Sideways Reflection, 144.

${ }^{48}$ Ibid., 139.

${ }^{49} \mathrm{Ibid} ., 157$.
} $660-682$.

(c) 2017 Kelly Louise Rexzy P. Agra

https://www.kritike.org/journal/issue 21/agra december2017.pdf

ISSN 1908-7330

(c) BY-NC-ND 
It is precisely this negativity which mobilizes the value of difference and the demand for respect; however, it is a form of respect not as tolerance, but rather, as intervention.

To return to Badiou, the 'respect of differences' is an advocacy that today is in fact characterized by a horror towards any vigorously sustained difference. ${ }^{50}$ He notes that "the celebrated 'other' is acceptable only if he is a good other." 51 This means that, "Just as there can be "no freedom for the enemies of freedom', so there can be no respect for those whose difference consists precisely in not respecting differences." $52 \mathrm{He}$ further derides: "Respect for differences, of course! But on condition that ... that which differs also respects, just as I do, the said differences." 53

Badiou notes that this is certainly not what Levinas had meant in his ethical radicalism, but this is how it appears to be manifested in our contemporary global world. It upholds the hidden attitude, that "only an Other who is like me, is deserving of respect." 54

From the point of view of Badiou's ethico-political philosophy, ethics itself is the assertion that yes, "there are only bodies and languages," but he adds, "except that there are [also] truths." 55 This means that there are not just differences and communities; there are also very authentic human gestures in the fields of science, politics, art, and love that cannot be reduced to strict animal parameters. They transcend the elementary necessity of everyday survival, and they are the halting point of differences, and are the real expressions of freedom. Badiou writes:

Freedom has nothing to do with the capacities of an ordinary body under the law of some language. Freedom is: active participation to the consequences of a new body, which is always beyond my own body. A truth-body which belongs to one of the four great figures of exception: love, politics, art and science; ... freedom is not a category of elementary life of bodies. Freedom is a category of intellectual novelty, not within, but beyond ordinary life. ${ }^{56}$

\footnotetext{
${ }^{50}$ Badiou, Ethics, 24.

${ }^{51}$ Ibid.

${ }^{52}$ Ibid.

${ }^{53}$ Ibid.

${ }^{54}$ Ibid.

${ }^{55}$ Badiou, Logics of Worlds, 4.

56 Alain Badiou, “Bodies, Languages, Truths," in Lacan dot com (2007),
} $<$ http://www.lacan.com/badbodies.htm $>$.

(c) 2017 Kelly Louise Rexzy P. Agra https://www.kritike.org/journal/issue 21/agra december2017.pdf 
Badiou is convinced that there should be no reason to "respect or vilipend" 57 differences in the first place; that the law of things is that our our life, as human animals, consists of particularities. ${ }^{58}$ He further states that "infinite alterity is quite simply what there is" 59 and that the real challenge of thought is rather the question of the 'same,' the question of the 'universal' that could cut across differences. One can love, solve a scientific problem, create a work of art, or fight for justice, regardless of race, gender, religion, class, or age.

Žižek supports Badiou on this thought and writes:

One of Badiou's great theses is that the pure multiple lacks the dignity of the proper object of thought: from Stalin to Derrida, philosophical common sense has always insisted on infinite complexity (everything is interconnected; reality is so complex that it is accessible to us only in approximations ...). Badiou implicitly condemns deconstructionism itself as the latest version of this common-sense motif of infinite complexity. Among the advocates of 'anti-essentialist' postmodern identity politics, for example, one often encounters the insistence that there is no 'woman in general', there are only white middle-class women, black single mothers, lesbians, and so on. One should reject such 'insights' as banalities unworthy of being objects of thought. The problem of philosophical thought lies precisely in how the universality of 'woman' emerges out of this endless multitude. ${ }^{60}$

Badiou stresses that we are "necessarily different." 61 The real challenge and problem is how to produce sameness or forms of unity, that is, how we can set ourselves up at the point where all of our differences do not prevent us from acting, thinking, and living together. To repeat: whether it is in the realm of art, politics, science, or love, the question of race, gender, religion, class, or age, should not be a problem, they should not even count. One can love, solve a scientific problem, create a work of art, fight for justice, while eating what

\footnotetext{
57 Alain Badiou, "Behind the Scarfed Law, There is Fear," in Islam Online Archive (3 March 2004), <https://archive.islamonline.net/?p=14999>.

${ }^{58}$ Ibid.

${ }^{59}$ Alain Badiou, Ethics, 26.

${ }^{60}$ Slavoj Žižek, The Ticklish Subject: The Absent Centre of Political Ontology (New York: Verso, 2000), 133.

${ }^{61}$ Alain Badiou, Philosophy and the Event: Alain Badiou with Fabien Tarby trans. Louise Burchill (USA: Polity, 2013), 41.

(c) 2017 Kelly Louise Rexzy P. Agra

https://www.kritike.org/journal/issue 21/agra december2017.pdf

ISSN 1908-7330
}

(cc) BY-NC-ND 
one is used to eat, wearing anything one wants or traditionally wears, praying to a deity or God, or not praying at all. Within these human endeavors in the fields of art, science, politics, and love, the domain of particularity is halted. Again, these are the kinds of human undertaking which basically transcend the brute fact of finitude, mortality, and diversity.

\section{Negation does not equate to Affirmation}

Finally, in the discussion of the current forms of social critique, Badiou runs the polemic that it is the moralism of Adorno's thought that regards the victimized body as the foundation of morality which he finds analogous with, if not a translation in, the democratic respect for human rights. ${ }^{62}$ Meanwhile, it is Negri's faith on capitalism transforming into a sort of communism which Badiou sees to be an acceptance of the capitalist order itself. ${ }^{63}$ This is something that Žižek also recognizes. He says that even Negri's final proposal for the focus of political struggle, viz., 'rights to global citizenship, minimal income, and access to and control over education, information and communication,' receives similar articulation in the universal human rights. ${ }^{64}$ In commenting on Negri, Žižek remarks that it is as if "one has only to drop the capitalist form, and the revolutionary goal is achieved." 65

It is the compatibility of Adorno and Negri's views with the existing order that Badiou regards the two as forms of critique which cannot be sustained if we are to envisage an idea of change in the contemporary world. Badiou announces that "the fundamental problem in the philosophical field today is to find something like a new logic." ${ }^{66}$ His philosophical position is to find what can be called an 'affirmative' dialectics, which, in contrast to 'negative' dialectics, is not a matter of negating the existing order as such but of thinking the possibility of the new itself. He wants "to find a dialectical framework where something or the future comes before the negative present." 67

${ }^{62}$ Badiou, “Affirmative Dialectics: from Logic to Anthropology," 2.

${ }^{63}$ Ibid.

${ }^{64}$ Slavoj Žižek, "Have Michael Hardt and Antonio Negri Rewritten The Communist Manifesto For The Twenty-First Century?," in Rethinking Marxism: A Journal of Economics, Culture E Society 13:34 (2001): 190-198.

${ }^{65}$ Žižek, Violence: Six Sideways Reflection, 16.

${ }^{66}$ Badiou, "Affirmative Dialectics: from Logic to Anthropology," 1.

${ }^{67} \mathrm{Ibid} ., 3$. The trajectory of Badiou's thought is towards founding a framework where affirmation comes first, having negation only as its consequence. His goal is to find "a way of reversing the classical dialectical logic inside itself so that the affirmation, or the positive proposition, comes before the negation instead of after it."

(c) 2017 Kelly Louise Rexzy P. Agra

https://www.kritike.org/journal/issue 21/agra december2017.pdf

ISSN 1908-7330

(cc) BY-NC-ND 
If one is to pursue the consequences of simple negation and critique, the problem involved in it can be summarized in three points. First, what it produces is a reactive kind of subjectivity that remains entangled to a previous order: to what it negates. Second, there is nothing in it that prevents the germination of a different oppressive order because it is obsessed with the current order. Third, it highlights the critical aspect of human agency but fails to account for human creativity as such. In following Badiou's point, the real challenge in making the ideal society possible is not simply to destroy an existing 'imperfect' regime, but more precisely to actually create the ideal society ground up, and only as a consequence, destroy the existing regime. ${ }^{68}$

Badiou thinks that affirmation must be 'the creation of something absolutely new, not in the form of a negation of what exists, but in the form of the newness inside what exists' ${ }^{69}$ He writes:

Really, in the end, I have only one question: What is the new in a situation? My unique philosophical question, 1 would say, is the following: Can we think that there is something new in the situation, not the new outside the situation nor the new somewhere else, but can we really think of novelty and treat it in the situation? ${ }^{70}$

It is not negation and then creation, but rather affirmation and creation within the situation of the old. ${ }^{11}$ This is the general orientation of the new logic he was in search of.

Our contemporary vision of ourselves in the eyes of Badiou is incapable of giving us insight on how we are to envisage and orient ourselves towards that "which brings to pass 'something other' than the situation," other than "opinions," other than "instituted knowledges."72 With democratic materialism, Badiou is worried about how we are to act at the wake of an event that disrupts the very coordinates of the world that we know; how we are to avert the germination of a radical and unforeseen form of evil if we are stuck with the horrors of totalitarianism as its acme-point; or how we can prevent meeting the great due dates of history by simply being seated worriedly in front of the television, watching; if the only thing we are convinced about is that we must live and be tolerant?

\footnotetext{
${ }^{68}$ Ibid., 4.

${ }^{69}$ Ibid., 5.

70 Alain Badiou, "Can Change Be Thought?" in Bruno Bosteels, Badiou and Politics (Durham \& London: Duke University Press, 2011), 307.

${ }^{71}$ Badiou, "Affirmative Dialectics: from Logic to Anthropology," 5.

72 Badiou, Ethics, 67.

(c) 2017 Kelly Louise Rexzy P. Agra

https://www.kritike.org/journal/issue 21/agra december2017.pdf

ISSN 1908-7330
}

(c) BY-NC-ND 
This line of discussion now takes us to the very heart of Badiou's philosophy: to why he declares that there is a need for a new dialectical logic, a reconstructed ontology, and a new form of ethics and theory of the subject, in lieu of "a new philosophical proposition adequate to ... creative novelty."73 Badiou singles out that politics, ethics, and philosophy are all plagued with the crisis of the negative. In taking the affirmative stance, he disagrees with the Hegelian dialectical logic that the negation of negation is a new affirmation. He asserts that today, "negativity, properly speaking, does not create anything new. It destroys the old, of course, but does not give rise to a new creation." ${ }^{74}$ For him, what we need to do instead, is to find a way to reverse "the classical dialectical logic inside itself so that the affirmation, or the positive proposition, comes before the negation instead of after it." 75 What we need is to make affirmation the essence of opening a new possibility, a new order of things, with negation only as a derivative, a consequence of creative novelty.

But what exactly is this new logic for? Badiou does not shy away in claiming that "there is no philosophy without the discontent of thinking in its confrontation with the world as it is."76 There is definitely something wrong with our state of affairs which our current theoretical frameworks fall short in assisting us as we confront it. In an interview on the self-evidence of Evil in our time, Badiou rather gives a sharp polemical remark:

Today we see liberal capitalism and its political system, parliamentarianism, as the only natural and acceptable solutions. Every revolutionary idea is considered utopian and ultimately criminal. We are made to believe that the global spread of capitalism and what gets called "democracy" is the dream of all humanity ... ${ }^{77}$

He adds:

In truth, our leaders and propagandists know very well that liberal capitalism is an inegalitarian regime, unjust,

\footnotetext{
${ }^{73}$ Badiou, "Affirmative Dialectics: from Logic to Anthropology," 1.

74 Alain Badiou, Filippo Del Lucchese, and Jason Smith, "We Need a Popular Discipline: Contemporary Politics and the Crisis of the Negative," in Critical Inquiry 3:4 (2008), 652.

${ }^{75}$ Badiou, "Affirmative Dialectics: from Logic to Anthropology," 3.

${ }^{76}$ Alain Badiou, Infinite Thought: Truth and the Return to Philosophy trans. and ed. by Oliver Feltham \& Justin Clemens (London: Continuum, 2003), 29.

77 Alain Badiou, “On Evil: An Interview with Alain Badiou, Christoph Cox and Molly Whalen," in Cabinet Magazine Online, (2001-2002), <http://www.cabinetmagazine.org/issues/5 Lalainbadiou.php>. Hereafter cited as "On Evil."
}

(c) 2017 Kelly Louise Rexzy P. Agra https://www.kritike.org/journal/issue 21/agra december2017.pdf ISSN 1908-7330 
and unacceptable for the vast majority of humanity. And they know too that our "democracy" is an illusion: Where is the power of the people? Where is the political power for third world peasants, the European working class, the poor everywhere? We live in a contradiction: a brutal state of affairs, profoundly inegalitarian-where all existence is evaluated in terms of money alone-is presented to us as ideal. To justify their conservatism, the partisans of the established order cannot really call it ideal or wonderful. So instead, they have decided to say that all the rest is horrible. Sure, they say, we may not live in a condition of perfect Goodness. But we're lucky that we don't live in a condition of Evil. Our democracy is not perfect. But it's better than the bloody dictatorships. Capitalism is unjust. But it's not criminal like Stalinism. We let millions of Africans die of AIDS, but we don't make racist nationalist declarations like Milosevic. We kill Iraqis with our airplanes, but we don't cut their throats with machetes like they do in Rwanda, etc. ${ }^{78}$

He further notes that:

Under the pretext of not accepting Evil, we end up making believe that we have, if not the Good, at least the best possible state of affairs-even if this best is not so great. The refrain of "human rights" is nothing other than the ideology of modern liberal capitalism: We won't massacre you, we won't torture you in caves, so keep quiet and worship the golden calf...79

That there is indeed Evil in our time which contemporary man is unable to address properly, is the conviction of Badiou. For him, what we need is not tolerance but intervention. Contemporary ethics, he says, "feeds too much on Evil and the Other." 80 Emancipatory politics is halted by its inability to "surpass the concept of a negation taken solely in its destructive and properly negative aspect." 81 And, contemporary orientations of

\footnotetext{
${ }^{78}$ Badiou, “On Evil."

${ }^{79} \mathrm{Ibid}$.

${ }^{80}$ Badiou, Ethics, 34.

${ }^{81}$ Badiou, Del Lucchese, and Smith, "We Need a Popular Discipline," 652.
}

(c) 2017 Kelly Louise Rexzy P. Agra

https://www.kritike.org/journal/issue 21/agra december2017.pdf

ISSN 1908-7330

(cc) BY-NC-ND 
philosophy ${ }^{82}$ reigned by linguistic relativism (or contemporary sophism as Badiou calls it) are all announcing the 'end' of philosophy. ${ }^{83}$ As such, there is a need for what he calls a (re)turn of philosophy, a reestablishment of its connection with politics, and a reconstruction of ethics. All of these, organized under the slogan: "There are only bodies and languages ... except that there are truths." 84

Here, we are to see the root of Badiou's polemic of ethical ideology. For him, the discourse of the Good, is not the discourse of 'what there is,' of the brute fact of mortality or of the self-evidence of difference. The Good is what we strive for, it is that which is not yet. ${ }^{85}$ Badiou's idea of the Good-life is nothing but the reassertion of the Platonic ideal of true-life, or of the Aristotelian gesture of living as an immortal. ${ }^{86}$ Furthermore, a truth, he says, is "that which punches a hole through knowledges." ${ }^{87}$ It is that which breaks away with consensus, with opinions, with the 'known' order of reality. In a very striking description, he refers to truth as an 'immanent break'. Immanent, "because a truth proceeds in the situation, and nowhere elsethere is no heaven of truths," and 'break,' "because what enables the truthprocess - the event-meant nothing according to the prevailing language and established knowledge of the situation." 88

For Badiou, the real question and challenge of thought and of life, is not the status of difference or survival, but the status of the same and the immortal. This means thinking and living in accordance to a singular and universal cause aimed at opening a new possibility within one's existing situation and of transforming from mortal-human-animals to immortalsingular-subjects. ${ }^{89}$ To him this is properly the question of truth and event.

\section{Subtractive Ontology}

In addressing the question of truth and event, Badiou notes that the first step is to determine their ontological status or to think about their being..$^{90}$ This is why the first of his planned three-volume work, Being and Event, ${ }^{91}$

82 Badiou points to the Hermeneutic orientation, Analytic orientation, and Postmodern orientation as the three general trajectories of contemporary philosophizing.

${ }^{83}$ See Badiou's discussion in "Philosophy and Desire," Infinite Thought, 29-42.

${ }^{84}$ Badiou, Logics of Worlds, 4.

${ }^{85}$ Badiou, Ethics, 27.

${ }^{86}$ Ibid., 12; Badiou, Logics of Worlds, 40.

${ }^{87}$ Badiou, Ethics, 70.

${ }^{88}$ Ibid., 42-43.

89 Ibid., 40.

${ }^{90}$ Badiou, Being and Event, 18.

${ }^{91}$ The second volume is Logics of Worlds, and the third volume is Immanence of Truths (which is yet to be written by Badiou).

(c) 2017 Kelly Louise Rexzy P. Agra

https://www.kritike.org/journal/issue 21/agra december2017.pdf

ISSN 1908-7330

(cc) BY-NC-ND 
deals with ontology, even if one of the underlying premises of Badiou's ontology is that it is different from philosophy. In Being and Event, Badiou argues that "mathematics, throughout the entirety of its historical becoming, pronounces what is expressible of being qua being." 92 For Badiou this is what allows philosophy to have a new basis.

Ontology, insofar as Badiou is concerned, is subtractive. He contrasts it to metaphysics which, for him, is the discourse of being as One. He cites G.W. Leibniz's metaphysical phrase that "What is not $a$ being is not a being." 93 Tzuchien Tho in his article "What Is Post-Cantorian Thought? Transfinitude and the Conditions of Philosophy" clarifies this and notes that "in its various expressions, metaphysics attempts to address reality through the speculative construction of its principles of organization." 94 Tho interprets that metaphysics for Badiou had always treated reality, or the world, under the criteria of oneness and unity. ${ }^{95} \mathrm{He}$ adds that for Badiou, however, ontology will only effectively deploy itself once it gets subtracted from the reign of totality and oneness. It is to this sense that Badiou's ontology is referred to as subtractive. Being is subtracted from the One, being is no longer considered as $a$ being but instead as nothing, ${ }^{96}$ since, to repeat Leibniz, "What is not $a$ being is not a being." 97 This 'nothing,' is what Badiou refers to as the pure multiple or the multiple of multiples. Being, for him, is not composed of atoms, ${ }^{98}$ which will still mean that being is composed of ones. Being is instead composed of multiplicities that are further composed of multiplicities and so on, that ends not in an ultimate one, but in a void. ${ }^{99}$ The scientific rendering of this 'void' or 'nothing' is for Badiou the job of ontology. Ontology then is the science of being's subtraction from unity, that is, being as pure multiplicity.

Badiou maintains that it is set theory in mathematics which had been able to provide a scientific rendering of pure multiplicity as such. Badiou in Meditation Three of Being and Event notes Bertrand Russell's key insight on the Barber Paradox and Georg Cantor's thesis on absolutely infinite multiplicities. Badiou remarks that the falsity of the speculative presupposition that 'nothing of a multiple can occur in excess of a wellconstructed language' or that "the master of words is also the master of the multiple" is what obliged set theory to "emerge recast and refounded, or

${ }^{92}$ Badiou, Being and Event, 8.

${ }^{93}$ Ibid., 23.

${ }^{94}$ Tzuchien Tho, "What Is Post-Cantorian Thought? Transfinitude and the Conditions of Philosophy" in Badiou and Philosophy, 23.

${ }^{95}$ Ibid., 23.

${ }_{96}$ Badiou, Being and Event, 388; Ethics, 53.

${ }_{97}$ Badiou, Being and Event, 23.

${ }_{98}$ Badiou, Philosophy and the Event, 106.

${ }^{99}$ Ibid., 106.

(c) 2017 Kelly Louise Rexzy P. Agra

https://www.kritike.org/journal/issue 21/agra december2017.pdf

ISSN 1908-7330

(c) BY-NC-ND 
rendered axiomatic." $100 \mathrm{He}$ stresses that "it so happens that a multiplicity (a set) can only correspond to certain properties and certain formulas at the price of the destruction (the incoherency) of the very language in which these formulas are inscribed." ${ }^{101}$ By this statement, he means that "the multiple does not allow its being to be prescribed from the standpoint of language alone." 102

Badiou demonstrates this through the well-known Barber's Paradox or Russell's Paradox. The paradox states the logical contradiction in the idea of a barber who shaves and does not shave himself at the same time. The paradox begins with the proposition that a barber is someone who shaves all those, and those only, who do not shave themselves. ${ }^{103}$ This proposition is then followed by the question: "Does the barber shave himself?" 104 The attempt to answer this question is what brings to the fore the apparent contradiction involved in the proposition. The barber cannot be shaving himself while at the same time being a barber, because the proposition states that the barber 'only' shaves those who do 'not' shave themselves. If he shaves himself, then he can no longer be the barber that shaves only those who do not shave themselves, because then, he would also be shaving those who shave themselves, i.e., himself.

The implication of this to set theory is that there is no such thing as 'a set of all sets'. ${ }^{105}$ Say the 'barber' is a 'set' symbolized as $p$, such that it is not an element of itself, that is, $p=\sim(p \in p)$; which in this case means that the barber cannot not belong to the set for which he is a barber: a barber of those who do not shave themselves. This is because if he belongs to the set of those who do not shave themselves, that is, $p=(p \in p)$, it will mean that he shaves and not shaves himself at the same time which is a contradiction. It will make $(p \in p)=\sim(p \in p)$ which is contradictory. The possible answer to the question then is for the barber to not shave himself at all $\sim(p \in p)$. But if this is the case, then he does belong to the set of those who do not shave themselves $(p \in p)$ and will commit the same contradiction $(p \in p)=\sim(p \in p)$.

Badiou then notes that "this equivalence of a statement and its negation annihilates the logical consistency of the language." 106 He adds: "inasmuch as we suppose that it counts a multiple as one, the 'set' $p$ is in excess here, of the formal and deductive resources of the language." 107 The

\footnotetext{
${ }^{100}$ Badiou, Being and Event, 40.

101 Ibid.

102 Ibid.

${ }^{103}$ Bertrand Russell, The Collected Papers of Bertrand Russell Vol. 8: The Philosophy of Logical Atomism, ed. by John Slater (Canada: Routledge, 1986), 228.

104 Ibid.

105 Tho, "What Is Post-Cantorian Thought?," 24.

${ }^{106}$ Badiou, Being and Event, 40.

107 Ibid., 41.
}

(c) 2017 Kelly Louise Rexzy P. Agra

https://www.kritike.org/journal/issue 21/agra december2017.pdf

ISSN 1908-7330 
property of $p$ is in excess or is 'larger' than $p$. The impossibility of the existence of a set that contains and does not contain itself as an element-like in the case of a set of all sets (since being a set, it must be included in itself) - is Badiou's departure point for asserting the impossibility of Oneness or totality or unity in being. The discussion of the excess in the set $p$ is the content of his ontology. He proceeds from the assertion of Cantor that "it is impossible to conceive the multiplicity as a unity, as a finite thing" and for that reason, such multiplicities are named "absolutely infinite multiplicities, or inconsistent ..."108 From this Cantorian assertion, Badiou argues that set theory enacts "that the one is not," or that "the absolute point of the being of the multiple is not its consistency but its inconsistency, a multiple-deployment that no unity gathers together." 109 Finally, he asserts that being is a multiple which is not a multiple of ones, or $a$ being, but a "multiple of multiples". ${ }^{110}$

\section{Being and the two kinds of multiplicity}

In his subtractive ontology, Badiou lays down two primary categories involved in this thought: 1) the category of being, which refers to the realm of 'what there is,'111 to the world as it is, or to the world according to our 'encyclopaedia of knowledge' ${ }^{112}$; and 2) the category of event, whose belonging to the category of being is by non-belonging, ${ }^{113}$ insofar as it manifests as a 'rupture' 114 with the established order of things, or a 'caesura' 115 and 'interruption'116 to the normalcy of everyday life situation.

As pointed out above, Badiou stresses that in the discussion of event, truth, and the subject, it is necessary to demonstrate the thinkability of their being. ${ }^{117}$ This means providing a philosophical elucidation of the arrival of an event-the singularity and novelty of which, interrupts the transcendental regime of a world-through the systematic inscription of the status of the void (that which is not being qua being) in ontology without reducing it to ontology's structural formalism. ${ }^{118}$ For Badiou, before we can give an account

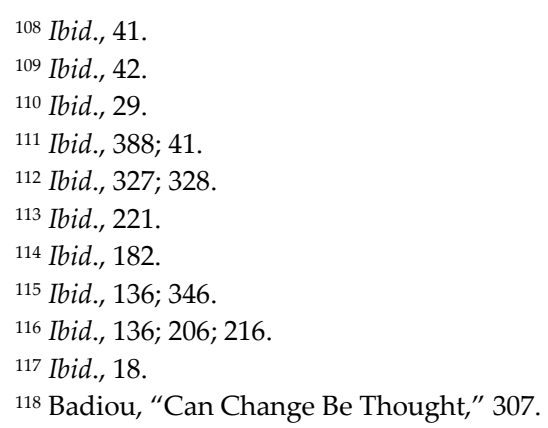

(c) 2017 Kelly Louise Rexzy P. Agra

https://www.kritike.org/journal/issue 21/agra december2017.pdf

ISSN 1908-7330

(c) BY-NC-ND 
of the event, there is the necessity of presenting first the structure of being, and how being could be supplemented. ${ }^{119}$

Badiou refers to any presented multiple as the situation having its own structure. ${ }^{120}$ Insofar as he is concerned, being can only 'present' itself as 'a multiple'. ${ }^{121}$ Without a structure, being will not be recognizable. What is there will only be a multiple of multiples. Being then, for him, is always recognized, or is only recognizable as a coherent situation, a structured multiplicity, with its own transcendental ordering (e.g., a conference of philosophers, Western world, a university, French culture, a laboratory, etc.). Badiou then interprets that being is nonetheless consisted by two kinds of multiplicities: inconsistent and consistent. ${ }^{122} \mathrm{He}$ explains, that if a situation is a structured multiplicity, it must be the case that there is a kind of multiplicity before it, not yet structured, which called for the necessity of the structure. ${ }^{123}$ It means that the structured multiple "structures" an initially unstructured multiple. He cautions though, that this unstructured-inconsistent multiple is something that can only be derived by 'retroactive apprehension.' ${ }^{24}$ For example, the structured multiple of human society would consist of multiples of multiples that do not refer to human society as such (e.g., atoms, germs, hairs, clothes, etc., that have their own set of multiple of multiples, and so on.). These multiples are in themselves incomprehensible to thought without a structure that will make them intelligible or consistent. In set theoretical rendering, because there is no set of all sets - a set that would contain itself as an element-there is a necessity for $a$ set, for being to be presentable.

What could be inferred in this structured multiplicity and unstructured multiplicity dualism is that every situation is basically split into double multiplicity. On one side there is inconsistent multiplicity which exists before structuration. On the other side, there is consistent multiplicity after structuration.

The structure that splits the situation into two is referred to by Badiou as the 'count-as-one'. ${ }^{125} \mathrm{He}$ also calls it the 'law' that "constrains the multiple to manifest itself as such [as inconsistent], and, what rules its structured composition [its consistency]." 126 The significance of this 'law' or 'count-asone' consists in making the multiple itself consist or structured and hence presentable. What this means is that it is the count-as-one or the law that allows presentation to take place.

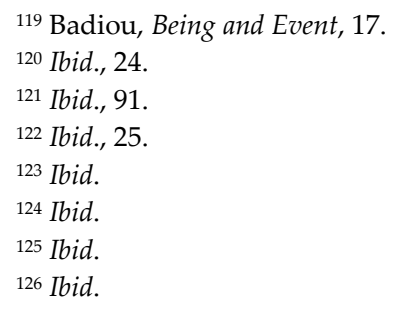


Badiou assesses the specific arcane involved in this statement. It begins with the puzzle that if being is one, it follows that the multiple is $n^{\prime} t^{\prime 27}$ However, this cannot be forwarded because at the level of presentation, being is multiple, and there is no other way through which being could be known except through presentation. Badiou then infers that it must be conceded that the multiple is. But if this is the case, again, it is unacceptable, because insofar as the multiple is concerned, it can only be thought as $a$ multiple if it is already assumed that it is one-a multiple with oneness. Now, in this elucidation lies the significance of the axiomatic claim of Badiou about double multiplicity. It has to be reckoned that Badiou in his assessment of being immediately presupposes the being of both oneness and multiplicity. But, oneness to him is not an ontological property of multiplicity as such but only the result of an operation in ontology. ${ }^{128}$ He writes that "there is no one, only the count-as-one." 129

Here, one can make a little remark that Badiou does not really say in Meditation One of Being and Event-where this discussion of being and situation is first laid out-what makes the operation operate, or what does the counting in the first place. If one has a more Kantian background, one could fall into understanding it as an operation of the mind or thought. This is in the sense that the mind is what organizes multiplicities and hence, what makes possible the presentation of the multiple first and foremost. And in this case, if one is Kantian, one might claim that the multiple presents itself 'to' thought. Thought then in its understanding of the multiple operates the multiple, it counts it as one, in order to be able to assert it as a multiple in its double sense (multiple before, and after).

It must be noted, however, that Badiou, is in no way Kantian on this dimension. For Badiou, the operation is part of ontology itself and not simply epistemology or an act of understanding. ${ }^{130}$ To Badiou, multiplicity is always counted. It is the law of presentation. It is always organized at the level of presentation, since as such, its initial state of inconsistency is unpresentable by itself. He traces this back to the Parmenidean thesis: "if the one is not, nothing is." 131 This means that without the count or a certain form of consistency or structure, 'there is nothing' or 'nothing is there.' This is why Badiou refers to inconsistent multiplicity as the void. ${ }^{132}$

127 Ibid., 23.

${ }^{128} \mathrm{Ibid} ., 24$.

129 Ibid., 24.

130 Alain Badiou, The Second Manifesto for Philosophy, trans. by Louise Burchill (Cambridge, UK: Polity Press, 2011), 30.

131 Plato, Parmenides, in The Dialogues of Plato, trans. by Benjamin Jowett (London: Oxford University Press, 1892), 166c.

132 Badiou, Being and Event, 58.

(c) 2017 Kelly Louise Rexzy P. Agra

https://www.kritike.org/journal/issue 21/agra december2017.pdf

ISSN 1908-7330

(c) BY-NC-ND 


\section{Void: the proper name of being}

The second aspect of Badiou's discussion rests on the claim that "the void is the proper name of being." 133 As such, this void is unpresentable, ${ }^{134}$ there is no access to it except via retroactive apprehension. The consistent multiplicity on the other hand, because of the fact that inconsistency is not presented as such, turns out to be the recognizable situation. Badiou writes:

... once the entirety of a situation is subject to the law of the one and consistency it is necessary, from the standpoint of immanence to the situation, that the pure multiple, absolutely unpresentable according to the count, be nothing. ${ }^{135}$

The pure multiple, as it is, is subtracted from the regime of presentation..$^{136}$

After this discussion of the void in Meditation Four, Meditation Eight introduces the idea of a second structure. Badiou calls this second structure as the 'metastructure.' If there is any definite function or feature of the metastructure, it is to make sure that "the void be nothing." 137 This means that none of its trace must even resurface within the regime of presentation. The metastructure as such, in fear of the void, re-structures the structure. ${ }^{138}$ It recounts the count. 139

At the level of the situation, if there is something that the law of the count is not able to count, it is the count itself. Badiou then identifies this as the point where the void could lurk. It is from this limit of the situation that the void could appear or manifest in the situation and disrupt consistency. ${ }^{140}$ To ensure that this will not happen, there is the necessity to count again the count, and establish that only what the count counts exists. ${ }^{141}$

Remember that in the discussion of sets, a set cannot be an element of itself because if it is, then it becomes contradictory. In set theory, there is that which is called Power-set. The Power-set is the set that includes all 'subsets' of a set. The Power-set axiom of set theory states that if a set exists, there also exists a 'set of all its subsets'; but one which is 'essentially distinct'

\footnotetext{
${ }^{133}$ Ibid., 52-59.

${ }^{134}$ Ibid., 58.

${ }^{135}$ Ibid., 53.

136 Ibid., 16; 54.

${ }^{137}$ Ibid., 94.

${ }_{138} \mathrm{Ibid} ., 84$.

139 Ibid.

${ }_{140}$ Ibid., 93.

${ }^{141}$ Ibid.
} 
from the initial set. ${ }^{142}$ For instance, set $\{a, b\}$, have elements $a$ and $b$. The Powerset of set $\{a, b\}$, have the elements $\{a\},\{b\},\{a, b\}$, and \{\} (or the empty set). Badiou notes that these two, despite being related, are different. The Power-set of $\{a, b\}$ which is symbolized as $P\{a, b\}$ is not the same with $\{a, b\}$, that is, $P\{a, b\}$ $\neq\{a, b\}$. The set is not necessarily similar to the set of all its subsets. There will always be at least one element of the Power-set $P\{a, b\}$ that is not an element of the initial set $\{a, b\}$ (i.e., $a \bullet b \neq\{a\} \bullet\{b\} \bullet\{a, b\} \bullet\{\}$ ).

It was already established earlier that the count tries to contain pure multiplicity and makes it consistent. If there is any point from which the pure multiplicity could manifest itself as such, it lies in the very count that tries to contain it. The count, because its base is pure multiplicity, can likewise become inconsistent, and as such, manifest the inconsistent multiplicity that it is. If what guarantees consistency is the count, and if the count itself becomes inconsistent, there will be nothing to stop the void from becoming visible. It is because of this that the metastructure is necessary, that which in set theory is rendered as the Power-set. There is a need for another structure, another count that will ensure that the count is also counted, that the set itself be a subset of itself; another law that will constrain it from letting the void appear. If there is double multiplicity, there is also a double structuration:

The apparent solidity of the world of presentation is merely a result of the action of structure, even if nothing is outside such a result. It is necessary to prohibit that catastrophe of presentation which would be its encounter with its own void, the presentational occurrence of inconsistency as such, or the ruin of the One.

Evidently the guarantee of consistency (the 'there is Oneness') cannot rely on structure or the count-as-one alone to circumscribe and prohibit the errancy of the void from fixing itself, and being, on the basis of this very fact, as presentation of the unpresentable, the ruin of every donation of being and the figure subjacent to Chaos. The fundamental reason behind this insufficiency is that something, within presentation, escapes the count: this something is nothing other than the count itself. ${ }^{143}$

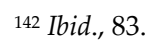

(c) 2017 Kelly Louise Rexzy P. Agra https://www.kritike.org/journal/issue 21/agra december2017.pdf ISSN 1908-7330 
For Badiou, this 'nothing' other than the count itself, is the void, represented in set theory as the null or empty set \{\} or $\emptyset$. A set counts a multiplicity as one. However, the empty set counts nothing precisely because it is empty. It does not have any element, not even itself, thus the symbolization, $\varnothing \notin \varnothing$ (which means the empty set is not an element of itself). However, in order to secure the counting of the count, it is recounted in the Power-set of the empty set, $P\{\}$. It is $P\{\}$ that has \{\} or $\emptyset$ as its element. Badiou writes further:

The 'there is Oneness' is a pure operational result, which transparently reveals the very operation from which the result results. It is thus possible that, subtracted from the count, and by consequence a-structured, the structure itself be the point where the void is given. In order for the void to be prohibited from presentation, it is necessary that structure be structured ... The consistency of presentation thus requires that all structure be doubled by a metastructure which secures the former against any fixation of the void. ${ }^{144}$

In this sense, "all situations are structured twice." 145 Within being, "there is always both presentation and representation." 146 If there is a situation, Badiou says, there is also a 'state of the situation'. ${ }^{147}$ For every set, there is a Power-set that counts even the count itself. However, because there is always something in representation, state-of-the-situation, or Power-set, that is in excess or not initially included in presentation, in a situation or in a set, the gap that separates the two provides avenue for the occurrence of what Badiou calls the 'supplement of being,' which he terms as the 'event.'

\section{IV: A Theory of Militant Subjectivity and An Ethic of Truths}

\section{The Event}

This is the point where Badiou begins to talk about the 'supplement' of being, that opens up a new possibility for it. This supplement, in the form of an event, is the manifestation of the void that is being. He writes: "the event is being, absolutely." 148 But at the same time, it is already "inappropriate" for

\footnotetext{
${ }^{144}$ Ibid., 93-94.

${ }^{145}$ Ibid., 94.

146 Ibid.

147 Ibid., 95.

${ }^{148}$ Badiou, "Can Change Be Thought," 307.
} 
being in the situation. ${ }^{149}$ What Badiou describes here, is the moment when the world as we know it, is interrupted in its regular flow.

The event, within the perspective of being, is that which it was unable to account for. It is what the world as it is, was unable to inscribe into its encyclopaedia of knowledge. In relation to this, Badiou puts the concept of truth in contrast to knowledge. ${ }^{150}$ Badiou aligns knowledge to the order of repetition ${ }^{151}$ while he aligns 'truth' to the order of singularity and newness. ${ }^{152}$ If knowledge is to being, truth is to event.

There are two relations which the event has to being. On the one hand, it is a rupture within being. On the other hand, it is the opening of a new possibility within and of being. Similarly, a truth's relation to the system of knowledges is two-way: First, it 'punctures a hole through it'; $; 153$ and second, it proposes a new ordering of these knowledges. ${ }^{154}$

The emergence of the event within the plane of being, in Badiou's description, consists of a double-event within the situation. First, it creates "a process of torsion, by which a force reapplies itself to that from which it conflictingly emerges"; $; 155$ and second, it transforms the coordinates of a system, degrees of existences, ${ }^{156}$ or distribution of possibilities ${ }^{157}$ within the situation. The first event is the moment of rupture, and the second one, is the 'interpretative intervention' 158 of a subject which inscribes in the situation the actual occurrence of an event.

Badiou highlights in Being and Event that the occurrence or nonoccurrence of an event is dependent on interpretative intervention. He describes intervention as "any procedure by which a multiple is recognized as an event." $159 \mathrm{He}$ adds the term 'interpretative' inasmuch as the belonging of the multiple to the situation is not a given, but a matter of 'interpretation'

149 Ibid.

${ }^{150}$ Badiou, Being and Event, 327-355.

${ }^{151}$ Badiou, "On the Truth-Process: An open lecture by Alain Badiou," in Lacan dot com (August 2002), $<$ http://www.lacan.com/badeurope.htm>.

152 Ibid.

153 Ibid.

154 Ibid.

${ }^{155}$ Cf. Bruno Bosteels, "Alain Badiou's Theory of the Subject: The Recommencement of Dialectical Materialism? (Part II)," in Pli Warwick Journal of Philosophy 13 (2002), 176.

${ }^{156}$ Badiou, The Second Manifesto for Philosophy, 43-63.

${ }_{157}$ Badiou, Philosophy and the Event, 9-12.

${ }^{158}$ Badiou, Being and Event, 181.

$159 \mathrm{Ibid} ., 202$. Bruno Bosteels explains that "the most important argument in all of Being and Event effectively holds that an event, which brings out the void that is proper to being by revealing the undecidable excess of representation, can only be decided retroactively by way of a subjective intervention. 'The impasse of being, which causes the quantitative excess of the state to wander beyond measure, is in truth the passe of the Subject.'" Bosteels, "Alain Badiou's Theory of the Subject (Part II)," 195.

(c) 2017 Kelly Louise Rexzy P. Agra

https://www.kritike.org/journal/issue 21/agra december2017.pdf

ISSN 1908-7330

(c) $\mathrm{BY}-\mathrm{NC}-\mathrm{ND}$ 
and 'decision.' 160 Badiou writes that "there cannot exist any regulated and necessary procedure which is adapted to the decision concerning the eventness of a multiple." $161 \mathrm{He}$ adds, "It will always remain doubtful whether there has been an event or not, except to those who intervene, who decide its belonging to the situation." 162

The event, for Badiou, is "only recognized by its consequences." 163 This includes the naming of the event (interventional nomination), the circulation of this name, ${ }^{164}$ and 'the existence of a subjective body.' ${ }^{165}$ These three are what constitute the material inscription and evidence of change within a situation. ${ }^{166}$

Through the name, the event gets to be incorporated into the situation, ${ }^{167}$ making its circulation within the situation possible. The affirmation of the event through the name is coextensive with the coming to existence of a 'subject.' The subject, Badiou defines, is "the process itself of liaison between the event (thus the intervention) and the procedure of fidelity (thus its operator of connection)"; 168 it is "any local configuration of a generic procedure from which a truth is supported." 169 The subject intervenes with the transcendental configuration of the situation by naming an indiscernible multiple (interventional nomination) and circulating it (fidelity to the event). ${ }^{170}$ The subject is what "incorporates the event into the situation"171 by naming it, circulating the name, and determining the multiples that are connected to the event within the situation. ${ }^{172}$ It is through this that the event properly becomes an event for a situation. ${ }^{173}$

\footnotetext{
160 Badiou, Being and Event, 183; 203.

161 Ibid., 201.

162 Ibid., 207.

$163 \mathrm{Ibid}$.

${ }^{164}$ Ibid., 207-211.

165 Badiou, "Affirmative Dialectics," 4.

166 Pluth, Badiou: A Philosophy of the New, 106.

${ }^{167}$ Badiou, Being and Event, 393.

168 Ibid., 239.

169 Ibid., 391.

${ }^{170}$ Ibid., 207-211.

${ }^{171}$ Ibid., 393.

172 Subjectivization, is a special count which "counts whatever is faithfully connected to the event." Ibid., 393.

${ }^{173}$ Peter Hallward, Badiou: A Subject to Truth (London: University of Minnesota Press, 2003), 13.
}

(c) 2017 Kelly Louise Rexzy P. Agra

https://www.kritike.org/journal/issue 21/agra december2017.pdf

ISSN 1908-7330 


\section{Subjectivization}

Badiou calls "the advent of the Two" of 'interventional nomination' and 'fidelity to the event,' as subjectivization. ${ }^{174}$ He notes that subjectivization is subtracted from the sense register of a situation. The name of the event and the existence of a subjective body do not have significance within the language and encyclopaedia of the situation. ${ }^{175}$ From the point of view of the situation, they simply do not make sense.

"This in-significance," Badiou writes, is "a reminder that what was summoned by the interventional nomination was the void."176 Thus, subjectivization, upon which an event is dependent, is itself "an occurrence of the void." 177 The process of subjectivization is an interruption to the coordinates of a situation. It is "an interruption of the law of representation inherent to every situation" which is what representation, the double count, or the metastructure prohibits. "If we now turn to the state of the situation," Badiou notes, "we see that it can only resecure the belonging of the supernumerary name, which circulates at random, at the price of pointing out the very void whose foreclosure is its function." ${ }^{178}$

This is where the seeming deadlock in Badiou's account of the event comes to the fore when he talks about the belonging of an event to a situation. The paradox is, if the state does not recognize the belonging of the evental multiple within the situation, it will assert this multiple's evental character. This means that the state will announce that the disruptive multiple is indeed something it was never able to anticipate, and is, therefore, beyond its control. However, if it asserts the multiple's belonging to the situation so as to bar its consequent interruption of the rules of the situation, it will do this at the price of forcing itself "to confess its own void"179:

By the declaration of the belonging of the event to the situation it bars the void's irruption. But this is only in order to force the situation itself to confess its own void, and to thereby let forth, from inconsistent being and the interrupted count, the incandescent non-being of an existence. ${ }^{180}$

${ }^{174}$ Badiou, Being and Event, 393.

175 Ibid.

176 Ibid.

177 Ibid. In the earlier parts of Being and Event Badiou writes: "The name of the event must emerge from the void." Badiou, Being and Event, 205; "The term chosen by the intervenor represents the void." Ibid., 206.

178 Ibid., 207.

179 Ibid., 183.

${ }^{180} \mathrm{Ibid}$.

(c) 2017 Kelly Louise Rexzy P. Agra

https://www.kritike.org/journal/issue 21/agra december2017.pdf

ISSN 1908-7330

(c) BY-NC-ND 
Badiou emphasizes how the event's belonging to the situation is always "undecidable," 181 and there can only be two interpretative interventions: either the event belongs to the situation or it does not. Consequently, there are two implications: either (1) the form of the multiple designated is evental; or, (2) with respect to this multiple, it is decided that it is a term of the situation. ${ }^{182}$ In this second implication, it will be as if "nothing will have taken place but the place itself," "when one makes two, there is never any return. It does not amount to making a new one, not even a new one." 183 In his interviews and the preliminary remarks to his books, Badiou always asserts that the primary question of his philosophy is to find out how a 'radically new' is possible 'within' a situation, while not being entirely reducible to it. However, it appears that there is some ambiguity in Badiou's elucidation alone that triggered a series of discussions between interpreters like Žižek and Bosteels. Returning to the discussion on subjectivization, it is then in the wake of an event that for Badiou, a truth-process may or may not emerge. A truth-process is that which a 'subject' produces in his committed fidelity to an event. ${ }^{184}$ The significance of an event, by being the material embodiment of the crack, the symptomal torsion within a situation, lies in its influence to induce a human animal into becoming a subject by deciding to invent a new way of being and acting within the situation in accordance to it. ${ }^{185}$ The event has the power to make evident the impossibility of things to remain the same or to stay as they are. ${ }^{186}$ It is the trigger point of change. It is what opens the possibility of that which is declared impossible within the situation. ${ }^{187}$ The event which is the coming into presence of the crack, the limit, or the inconsistency, the void of being itself, is what opens up the possibility of a reordering of being. ${ }^{188}$ This reordering is what Badiou refers to as the truth-process.

There is, however, yet a very crucial role played here by the subject. The subject, as Ed Pluth describes it, is the "actual material inscription of change,"189 or the concrete affirmation that an event 'actually' happened.

\footnotetext{
181 Ibid., 201.

182 Ibid., 202.

${ }^{183}$ Cf. Alain Badiou, Theory of the Subject, 126; Bruno Bosteels, "Alain Badiou's Theory of the Subject: Part II," 179.

184 Badiou, Ethics, 41.

${ }^{185}$ Ibid., 42.

186 Slavoj Žižek, "From Purification to Subtraction: Badiou and the Real," in Think Again: Alain Badiou and the Future of Philosophy ed. by Peter Hallward (London: Continuum, 2004), 175.

187 Badiou, Being and Event, 86.

188 Badiou, "On the Truth-Process."

189 Ed Pluth, Badiou: A Philosophy of the New, 106.
}

(c) 2017 Kelly Louise Rexzy P. Agra https://www.kritike.org/journal/issue 21/agra december2017.pdf ISSN 1908-7330 
Unless, there is a subject that would affirm an event, there is only the continuation of the current order, and as such, no truth-process. ${ }^{190}$ A truthprocess only 'begins,' at the moment when one 'decides' to act according to the new possibility opened by an event, and thus to live through "a sustained investigation of the situation, under the imperative of the event itself." 191 Badiou further defines the subject as "the bearer of a fidelity, the one who bears a process of truth," 192 the material embodiment of the consequence of the event. However, only until an absolute decision is made at the 'night of being,' at the irruption of the unsettling undecidability of the event's relation to the situation, will a new subjective body emerge. It is an 'absolute' decision for one will never 'know' nor 'calculate' nor be 'certain' of what will a new way of going about things will amount to, and this is why Badiou attaches the spirit of fidelity characterized by militancy to the subject. ${ }^{193}$ Within subjective fidelity, the element of resistance, the element of doubt, and the element of exhaustion are the very challenges against which one must strive. To be a subject is to have a disciplined commitment to a decision for a prolonged disorganization of one's life. ${ }^{194}$ To be a subject of a truth is to be a militant for a cause. It "requires effort, endurance, sometimes self-denial." It is to be an "'activist' of a truth." 195

\section{The ethic of truth-processes}

This elaboration of organizing one's life according to processes that labour to bring some truths into the world is basically what Badiou refers to as ethic of processes ${ }^{196}$ or truth-processes. It is in the plural because as Badiou writes, "There is not, in fact, one single Subject, but as many subjects as there are truths." 197 However, one must not mistake this as falling into the very relativism which Badiou is arguing against. Because despite the plurality of truths, produced within the four figures of exception: science, art, love, and politics; every truth, by virtue of its singularity is "subtracted from identitarian predicates." 198 Even if they proceed from particularities, they are

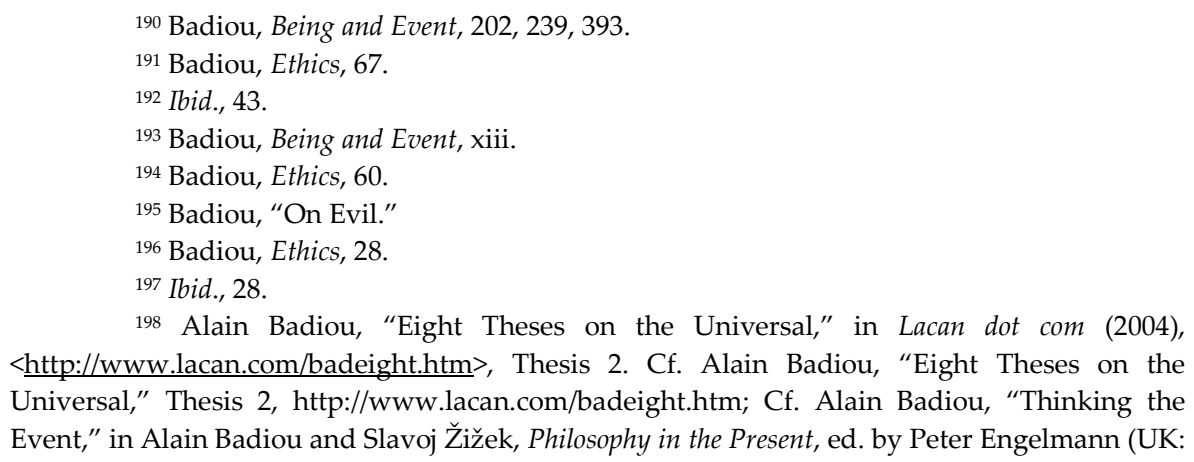
Universal," Thesis 2, http://www.lacan.com/badeight.htm; Cf. Alain Badiou, "Thinking the Event," in Alain Badiou and Slavoj Žižek, Philosophy in the Present, ed. by Peter Engelmann (UK: Polity Press, 2009).

(c) 2017 Kelly Louise Rexzy P. Agra https://www.kritike.org/journal/issue 21/agra december2017.pdf ISSN 1908-7330 
subtracted from such particularities, and are in their nature universal by virtue of their 'exceptional' production. ${ }^{199}$ They are those that are truly "indifferent to differences" 200 and are founded on the principle of infinity. They are those which in Badiou's words, can "interest, rightly, 'every' human individual, according to his/her 'generic' humanity." 201 Badiou argues that it is actually "in recognizing the capacity of differences to carry the universal which comes upon them, that the universal can verify its reality." 202 It is to this end that he calls them singular. But these singularities are exceptions that go beyond the hold of particularities despite their particular origins. Commenting on this, Peter Hallward notes, "Justice must be for everyone, or it is for no one." 203 For Badiou, this ethic is not a general configuration of Ethics, which for him does not exist. But rather, it is an ethic of ..., that is, of procedures of truth.

If we are to look at issues today which could give us a picture of what Badiou is pointing out as the inconsistency of a situation which in fact sustains every consistent situation, a good example would be the case of Korean veterans in Japan, Muslim women in France, African Americans in the United States, or the Pariahs in India. They are, to use Badiou's terms, the 'outplace,' the uncounted, the unrepresented, within the state (the unified Japanese race, the secular French government, the white American people, the members of the Indian chaturvarnas). Situated 'on the edge of the void,' they contain the "absolutely primary terms" of the situation. ${ }^{204}$ They are "the 'lie' of the ancient regime" 205; the truth that it had to repress, the proof of the state's inherent inconsistency and excess which it had to suppress in order to secure its own consistency and sustain its structure. What it indicates is an advocacy of tolerance and respect of differences (One Japan; Equality,

199 This passion for the 'universal,' the 'exceptional, the 'same,' is in Badiou's philosophical edifice, the pursuit of truth. 'Exception' is another term Badiou uses to refer to truth - as in the case of 'figures of truth' he also refers to it as 'figures of exception.' Truth, Badiou interprets, belongs to the order of exception, and it is a 'procedure' rather than a fact, or some correspondence between object and knowledge. This is why Badiou more often calls the four figures of exception as truth procedures. For Badiou they are exceptions because they are the kind of practical human endeavors that go beyond and interrupt everyday routine and survival. The character of exception is what renders truths universal and singular. They are universal in the sense that they do not privilege any specific difference. Their exceptionality -in contrast to normality -is what makes them accessible, intelligible, or recognizable to everyone as well as what makes everyone capable of pursuing them.

200 Badiou, Ethics, 27.

${ }^{201}$ Badiou, "On Evil."

202 Alain Badiou, Saint Paul: The Foundation of Universalism trans. by Ray Brassier (Stanford: Stanford University Press, 2003), 106.

${ }^{203}$ An allusion to Peter Hallward's statement: "true justice is either for all or not at all."

Hallward, Badiou: A Subject to Truth, 26.

${ }^{204}$ Badiou, Being and Event, 175.

${ }^{205}$ Žižek, The Ticklish Subject, 130.

(c) 2017 Kelly Louise Rexzy P. Agra

https://www.kritike.org/journal/issue 21/agra december2017.pdf

ISSN 1908-7330

(cc) BY-NC-ND 
Fraternity, Liberty; Democracy; Harmony) that actually prescribes an identity - the identity of the state. ${ }^{206}$ Such cases are in Badiou's ethico-political thought, what manifest the communitarian-particularist ideology's halting point, its crack and impasse.

Returning to the topic of ethics, Badiou observes that at the heart of the ethical wisdom of an ethic of universal human rights, what remains is always only the power to decide who dies and who does not. ${ }^{207}$ That beneath all the projected spirit of brotherhood, only those in power, or better yet, those who have money, are capable of exercising 'freedom' and enjoy 'equality.' Badiou retorts lengthily:

Isn't there a lot of despair and violence in the world caused by the fact that the politics of Western powers, and of the American government in particular, are utterly destitute of ingenuity and value? ... The whole world understands that the real question is the following: Why do the politics of the Western powers, of NATO, of Europe and the USA, appear completely unjust to two out of three inhabitants of the planet? Why five thousand American deaths are considered a cause for war, while five hundred thousand dead in Rwanda and a projected ten million dead from AIDS in Africa do not, in our opinion, merit outrage? Why is the bombardment of civilians in the US Evil, while the bombardment of Baghdad or Belgrade today, or that of Hanoi or Panama in the past, is Good? ... The whole world understands these situations, and the whole world can act in a disinterested fashion prompted by the injustice of these situations. Evil in politics is easy to see: It is absolute inequality with respect to life, wealth, power. Good is equality. How long can we accept the fact that what is needed for running water, schools, hospitals, and food enough for all humanity is a sum that corresponds to the amount spent by wealthy Western countries on perfume in a year? This is not a question of human rights and morality. It is a question of the fundamental battle for equality of all people, against the law of profit, whether personal or national. ${ }^{208}$

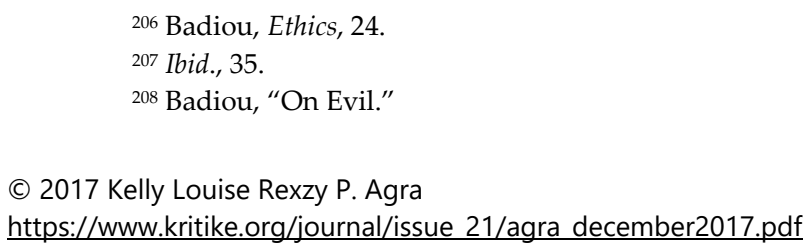


At the core of all these, Badiou's message strikes us with an incisive frankness: today, we need no less than a theory, a general framework that would assist us in knowing what must be done, and an ethic that would encourage us to be militants for something true, for a cause, for the Good. What we need is an emancipatory politics that is supported by an ethic, thought through philosophy. For Badiou, this is the role of philosophy: to give insight on 'What is the Good?' Badiou writes in his Theory of the Subject that all of his philosophy is aimed at preventing us from becoming one who "can only meet the great dates of history by distributing herring vouchers." 209 It is inspired by the Lacanian optimisim: "Fortify yourself if you can, ... 'it makes no sense for life to create cowards'." 210

Following through the discussion one may ask whether Badiou is trying to restore the revolutionary spirit, which, in the twentieth century had catastrophic consequences, or whether he is reviving something like the communist projects of Lenin, Stalin, or Mao. The answer to this lies in Badiou's analysis of why the communist projects of the past failed. For him, their political determination tried to maintain a relation, between pure subjective will and implacable historical necessity. ${ }^{211}$ Definitely, Badiou's theory of militant subjectivity is a revival of the activist stance. However, it is a militant subjectivity subtracted from objective necessity. That is why Badiou's ethic of truths rests on an absolute wager. ${ }^{212}$ Badiou strongly stresses that becoming a passage of truth requires courage. It goes against a life that has resigned its significance to mere survival, the luxuries of merchandise, and the obsession to security. It is a life constructed around that which one is willing to risk for, around what he calls an "Idea" which he described as "the possibility in the name of which you act, you transform and you have a programme." 213 The Idea is "the conviction that a possibility, other than what there is, can come about." ${ }^{214}$ It is the name for the possibility the subject tries as much to inscribe in an existing situation that declares it impossible-the possibility opened up by the event. To live life according to the Idea, Badiou remarks, is to live a life of 'immortal intensity' that is founded on absolute uncertainty. It is a life that finds motivation in the ethical maxim:

... 'do not give up on that part of yourself that you do not know.' ... do not give up on your own seizure by a

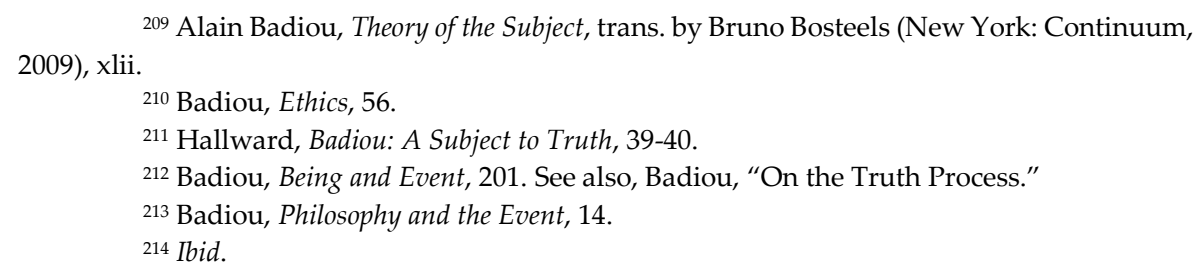


truth-process.... 'Do all that you can to persevere in that which exceeds your perseverance. Persevere in the interruption. Seize in your being that which has seized and broken you.'215

\section{Conclusion}

To conclude this paper, I would like to describe Badiou's take on subjectivity as subjectivity to the call of truth. It is a subjectivity of a body that took it upon itself to pursue or incarnate the true life. Drawing from the discussion laid out here, it appears that one of the purposes of philosophy for Badiou is to think about the possibility of this subject. ${ }^{216}$ In my analysis, Badiou's solution to the crisis we are experiencing at the objective level is not immediately a change of the existing objective order, for as he himself admits that we are not too powerful to do that. ${ }^{217}$ What he proposes instead, is a change in contemporary subjectivity, hoping that this could prepare the way to the establishment of a new order. In other words, it is a change in the objective order by way of the subject. This I think is the Badiouian philosophical response to the question "How to change the world?" In his political texts, he writes exhaustively too on the concrete problems and changes he wants to address and do respectively. But his philosophical thought shows much promise insofar as it provides us a framework that enables us to confront the crises of our contemporary situation with courage and the hope for the impossible. Perhaps indeed, what he fought for in the student revolution of May 1968 in France remained in him, as he still endorses their rallying cry: “Declare the impossible!" 218

Department of History and Philosophy, University of the Philippines Baguio, Pbilippines

\section{References}

Adorno, Theodor, Metaphysics: Concepts and Problems trans. by Edmund Jephcott (Cambridge: Polity Press, 2001).

Negative Dialectics trans. by E.B. Ashton (New York: Continuum, 1999).

\footnotetext{
215 Badiou, Ethics, 47.

${ }^{216}$ Badiou, Being and Event, 6.

217 Badiou, "On Optimism."

${ }^{218}$ Badiou, Philosophy and the Event, 11.
}

(c) 2017 Kelly Louise Rexzy P. Agra

https://www.kritike.org/journal/issue 21/agra december2017.pdf

ISSN 1908-7330

(c) BY-NC-ND 
Agra, Kelly, "The World as 'Is' and the World as 'Ought': Contemporary Philosophy and the Crisis of Subjectivity," in Philosophy in the Contemporary World 22:2 (2015).

Thinking in the End Times: From Logic to Anthropology," in Social Science Teaching, Research and Practice: Consolidating Lessons and Charting Directions (Conference Papers, Vol. 1), ed. by Lorelei C. Mendoza (Baguio City: College of Social Sciences, University of the Philippines Baguio, 2016).

Badiou, Alain, "Affirmative Dialectics: from Logic to Anthropology," in The International Journal of Badiou Studies, 2:1 (2013).

Being and Event, trans. by Oliver Feltham (New York: Continuum, 2005).

"Behind the Scarfed Law, There is Fear," in Islam Online Archive

(3 March 2004). <https://archive.islamonline.net/?p=14999>.

"Bodies, Languages, Truths," in Lacan dot com (2007), $<\underline{\text { http://www.lacan.com/badbodies.htm }>\text {. }}$

"Can Change Be Thought?" in Bruno Bosteels, Badiou and Politics

(Durham \& London: Duke University Press, 2011).

, Badiou, "Eight Theses on the Universal," in Lacan dot com (2004),

$<$ http://www.lacan.com/badeight.htm $>$.

"Ethic of Truths," in Pli: Warwick Journal of Philosophy 12 (2001).

Ethics: An Essay on the Understanding of Evil trans. Peter Hallward

(New York: Verso, 2000).

Infinite Thought: Truth and the Return to Philosophy trans. and ed.

by Oliver Feltham \& Justin Clemens (London: Continuum, 2003).

Logics of Worlds, trans. by Alberto Toscano (London: Bloomsbury, 2013).

"On Evil: An Interview with Alain Badiou, Christoph Cox and Molly Whalen," in Cabinet Magazine Online, (2001-2002), $<$ http://www.cabinetmagazine.org/issues/5/alainbadiou.php $>$.

_ "On Optimism," The Nexus Institute (2012), 07:30, <http://y2u.be/o6O d1DVk3U>.

"On the Truth-Process: An open lecture by Alain Badiou," in

Lacan dot com (August 2002), <http://www.lacan.com/

badeurope.htm>.

Philosophy and the Event: Alain Badiou with Fabien Tarby trans. Louise Burchill (USA: Polity, 2013).

Saint Paul: The Foundation of Universalism trans. by Ray Brassier

(Stanford: Stanford University Press, 2003).

The Second Manifesto for Philosophy, trans. by Louise Burchill

(Cambridge, UK: Polity Press, 2011).

(c) 2017 Kelly Louise Rexzy P. Agra

https://www.kritike.org/journal/issue 21/agra december2017.pdf

ISSN 1908-7330 
Theory of the Subject, trans. by Bruno Bosteels (New York: Continuum, 2009).

"Thinking the Event," in Alain Badiou and Slavoj Žižek, Philosophy in the Present, ed. by Peter Engelmann (UK: Polity Press, 2009).

Badiou, Alain and Slavoj Žižek, Philosophy in the Present, ed. by Peter Engelmann (UK: Polity Press, 2009).

Badiou, Alain, Filippo Del Lucchese, and Jason Del Smith, "We Need a Popular Discipline: Contemporary Politics and the Crisis of the Negative," in Critical Inquiry 3:4 (2008).

Bosteels, "Alain Badiou's Theory of the Subject: The Recommencement of Dialectical Materialism? (Part II)," in Pli Warwick Journal of Philosophy 13 (2002).

Fisher, Mark, Capitalist Realism: Is There No Alternative (UK: O Books, 2009).

Fukuyama, Francis, The End of History and the Last Man (New York: The Free Press, 1992).

“The End of History?" in The National Interest 16 (1989).

Hallward, Peter, Badiou: A Subject to Truth (London: University of Minnesota Press, 2003).

Horkheimer, Max and Theodor Adorno, Dialectic of Enlightenment: Philosophical Fragments trans. by Edmund Jephcott (Stanford, California: Stanford University Press, 2002).

Johnston, Adrian, Badiou, Žižek and Political Transformations: The Cadence of Change, (USA: Northwestern University Press, 2009). Prolegomena to Any Future Materialism - Volume One: The Outcome of Contemporary French Philosophy (Illinois: Northwestern University Press, 2013).

Plato, Parmenides, in The Dialogues of Plato, trans. by Benjamin Jowett (London: Oxford University Press, 1892).

Pluth, Ed, Badiou: A Philosophy of the New (New York: Polity Press, 2010). "The Black Sheep of Materialism: The Theory of the Subject," in Badiou and Philosophy ed. by Sean Bowden and Simon Duffy (Edinburgh: Edinburgh University Press, 2012).

Russell, Bertrand, The Collected Papers of Bertrand Russell Vol. 8: The Philosophy of Logical Atomism, ed. by John Slater (Canada: Routledge, 1986).

Tho, Tzuchien, "What Is Post-Cantorian Thought? Transfinitude and the Conditions of Philosophy" in Badiou and Philosophy, ed. by Sean Bowden and Simon Duffy (Edinburgh: Edinburgh University Press, 2012).

United Nations General Assembly, Resolution 217 A, "The Universal Declaration of Human Rights," 10 December 1948,

(c) 2017 Kelly Louise Rexzy P. Agra

https://www.kritike.org/journal/issue 21/agra december2017.pdf

ISSN 1908-7330

(c) $\mathrm{BY}-\mathrm{NC}-\mathrm{ND}$ 
$<$ http://www.un.org/en/universal-declaration-human-rights/ index.html >.

Žižek, Slavoj, "Badiou: Notes From an Ongoing Debate," in International Journal of Žižek Studies, 1:2 (2007).

"From Purification to Subtraction: Badiou and the Real," in Think Again: Alain Badiou and the Future of Philosophy ed. by Peter Hallward (London: Continuum, 2004).

"Have Michael Hardt and Antonio Negri Rewritten The Communist Manifesto For The Twenty-First Century?," in Rethinking Marxism: A Journal of Economics, Culture E Society 13:34 (2001). Living in the End Times (London: Verso, 2010). The Ticklish Subject: The Absent Centre of Political Ontology (New York: Verso, 2000).

"Tolerance as an ideological category," in Critical Inquiry 34:4 (2008).

Violence: Six Sideways Reflection (New York: Picador, 2008). 